\title{
Mild Versus Moderate Exercises on Glucose Level in Type 2 Diabetes Mellitus Patients
}

\author{
HANY M.Gh. ABD EL-AZIZ, Ph.D. ${ }^{\mathbf{1}}$; ZAHRA M.H. SERRY, Ph.D. ${ }^{\mathbf{1}}$; DINA M. ABAZA, M.D. ${ }^{2}$; \\ NAGWA A. MOHAMMED, M.D. ${ }^{3}$ and GIHAN S. MOHAMED, Ph.D. ${ }^{4}$ \\ The Department of Physical Therapy for Cardiovascular/Respiratory Disorder \& Geriatrics, Faculty of Physical Therapy, \\ Cairo University ${ }^{\prime}$, The Department of Endocrinology \& Metabolism, Faculty of Medicine, Al-Azhar University for Girls 2 , \\ The Departement Clinical \& Chemical Pathology, National Research Center ${ }^{3}$, Egypt and The Department of Physical Therapy, \\ Faculty of Applied Medical Sciences, Umm Al-Qura University, Kingdom of Saudi Arabia ${ }^{4}$
}

\begin{abstract}
Background: Glucose level is increased in diabetic patient and exercise is an important method in decreasing fasting and postprandial glucose level.

Aim of Study: The main objective of this study was to determine the effect of mild exercises versus moderate exercise on glucose level in patients with type 2 diabetes.

Subject and Methods: 40 patients (men and women) diagnosed with type 2 diabetes (non-insulin dependant diabetes mellitus) with age ranged from 50 to 60 years old. They were selected from medical Health insurance clinic in Misr ElGedida. They were divided into two groups. Group A included 20 patients participated in mild exercise in form of 10 minute walking program 3 times weekly for two months and Group $B$ included 20 patients participated in a moderate exercise in form of 10 minute walking program 3 times weekly for two months. Blood sample for measuring fasting and postprandial glucose level before and after exercise program.
\end{abstract}

Results: It showed that in most measures the rate of decrease of fasting and postprandial glucose level in group B who participated moderate exercise is greater than Group A who participated mild exercise.

Conclusion: Participatingexercise decreases fasting and postprandial glucose level in patients with type 2 diabetes. Moderate exercise had a greater effect on decreasing glucose level than mild exercise.

Key Words: Fasting blood glucose level - Type 2 diabetes mellitus - Mild and moderate exercise - Postprandial glucose level.

\section{Introduction}

DIABETES mellitus is a complex metabolic disorder characterized by persistanthyperglycaemia, hyperlipidemia due to in adequate insulin produc-

Correspondence to: Dr. Hany M.G. Abd El-Aziz,

The Department of Physical Therapy for Cardiovascular/ Respiratory Disorder \& Geriatrics, Faculty of Physical Therapy, Cairo University, Egypt tion or ineffective insulin action. Diabetes mellitus is one of the major health problem facing our nation, it is a common disorder whose prevalence is steadily increasing, about 15 million Americans or about $5 \%$ of the population are estimated to have diabetes mellitus. The disease ranks as the sixth or seventh leading cause of mortality in United States and is direct underlying cause of at least 40,000 deaths annually [1]

Diabetes mellitus is a chronic life long condition that affects your body's ability to use the energy found in food. There are three major types of diabetes: Type 1 diabetes, type 2 diabetes and gestational diabetes. All types of diabetes mellitus have something in common. Normally your body breaks down the sugars and carbohydrates you eat into a special sugar glucose. Glucose fuels the cells in your body. But the cells need insulin, a hormone, in your bloodstream in order to take in the glucose and use it for energy. With diabetes mellitus, either your body doesn't make enough insulin, it can't use the insulin it does produce, or a combination of both. Since the cells can't take in the glucose, it builds up in your blood [2].

Type 1 diabetes is also called insulin dependent diabetes. It used to be called juvenile onset diabetes, because it often begins in childhood. Type 1 diabetes is an autoimmune condition. It's caused by the body attacking its own pancreas with antibodies. In people with type 1 diabetes, the damaged pancreas doesn't make insulin. This type of diabetes may be caused by a genetic predisposition. It could also be the result of faulty beta cells in the pancreas that normally produce insulin. A number medical risks are associated with type 1 diabetes. Many of them stem from damage to the tiny blood vessels 
in your eyes (called diabetic retinopathy), nerves (diabetic neuropathy) and kidneys (diabetic nephropathy). Even more serious is the increased risk of heart disease and stroke.A periodic test called the $\mathrm{A}_{1 \mathrm{C}}$ blood test estimates glucose levels in your over the previous three months.organ damage [3]

Type 2 diabetes mellitus is characterized by insulin resistance, which may be combined with relatively reduced insulin secreation. The defective responsiveness of body tissues to insulin is believed to involve the insulin receptor. However, the specific defects are not known. Diabetes mellitus cases due to a known defect are classified separately. In early stage of type 2 , the predominant abnormality is reduced insulin sensitivity. At this stage, hyperglycemia can be reserved by a variety of measures and medications that improve insulin sensitivity or reduce glucose production by the liver [4]

Mild exercise is open to some subjective variation; what an experienced marathon runner considers "mild" would be tremendously daunting to someone with a sedentary lifestyle. In general, though, if your doctor recommends mild exercise, examples of appropriate activities might include brisk walking, leisurely biking or gentle calisthenics. Before starting a new exercise program, consult with your primary care provider, especially if you are uncertain about the appropriate intensity level for your condition. Mild exercise isn't just something for the infirm and elderly. If your schedule or energy level won't accommodate more intensive workouts, mild to moderate workouts can dramatically improve your health [5].

Physical exercise is any bodily activity that enhances or maintains physical fitness and overall health and wellness. It is performed for various reasons, including strengthening muscles and the cardiovascular system, honing athletic skills, weight loss or maintenance, and merely enjoyment. Frequent and regular physical exercise boosts the immune system and helps prevent the "diseases of affluence" such as heart disease, cardiovascular disease, type 2 diabetes, and obesity. Generally, light-to-moderate intensity activities that are sufficiently supported by aerobic metabolism can be performed for extended periods of time [1]. When practiced in this way, examples of cardiovascular/ aerobic exercise are medium to long distance running/jogging, swimming, cycling, and walking [14]

Aerobic exercise comprises innumerable forms. In general, it is performed at a moderate level of intensity over a relatively long period of time. One meta-analysis has shown, from multiple conducted studies, that aerobic exercise does help lower $\mathrm{HbA}_{1 \mathrm{C}}$ levels for type 2 diabetics [13].

\section{Subjects and Methods}

This study was conducted in Medical Health Insurance Misr El-Gedida clinic from May 2015 to November 2016 to assess the effect of mild versus moderate exercise on blood glucose level in patients with type 2 diabetes.

\section{I- Subjects:}

40 patients (men and women) participated in this study with type 2 diabetes mellitus.

They were divided into two groups:

- Group (A): 20 patients participated in mild exercise in form of 10 minute walking program 3 times weekly for two months.

- Group (B): 20 patients participated in a moderate exercise in form of 10 minute walking program 3 times weekly for two months.

There were 5 minutes warm-up in form stretching exercise and also 5 minutes cool down exercise in form of stretching exercise for both groups of patients.

\section{Inclusive criteria:}

Patients have the following:

- Taking medical treatment for diabetes regularly with regular follow-up visits for outpatients clinic.

- Fasting blood glucose level above $160 \mathrm{mg} / \mathrm{dl}$.

- Patients initially diagnosed as type 2 diabetes with no signs for diabetic foot.

- Able to understand the purpose of exercise.

\section{Equipment:}

A- For evaluation: Blood sample for measuring fasting and postprandial glucose level before and after exercise program.

Fasting and postprandial blood glucose was determined on Dimension RxL Max analyzer (Siemens Healthcare GmbH-Henkestr. 127, 91052 Erlangen, Germany) by colorimetric techniques.

\section{Training procedure:}

Group (A) twenty patients participated under supervised aerobic exercises program (mild exercise) in form of walking on motorized treadmail for 10 minutes performed 3 times per week for 2 months. Up to $50 \%$ of their maximam heart rate.

Group (B) twenty patients participated under supervised aerobic exercises program (moderate 
exercise) in form of walking on motorized treadmail for 10 minutes performed 3 times per week for 2 months up to $50 \%$ to $60 \%$ of their maximam heart rate (Travers, 2015).

- Maximam Heart Rate formula (MHR) : Subtract your age from 220 to get your maximum heart rate.

- Next, subtract your resting heart rate from your maximum heart rate.

Multiply that number by your percentage of training intensity. Then add your resting heart rate to get your target heart rate [8].

There were 5 minutes warm-up in form stretching exercise and also 5 minutes cool down exercise in form of stretching exercise for both groups of patients.

\section{Statistical analysis:}

Data concerning each patient for both groups were collected in the first evaluation including, inflammatory cytokines (IL1 and IL6). These data were collected after 2 months after performing exercise for both groups in the final evaluation. Descriptive analysis (mean \pm SD) before \& after 2 months $t$-test were used in treatment of the data of the study and also between men and women.

\section{Results}

Table (1): Shows comparison between fasting blood glucose level before and after exercises in both groups.

\begin{tabular}{|c|c|c|c|c|}
\hline \multirow[b]{2}{*}{ Fasting } & \multicolumn{2}{|c|}{ Group } & \multicolumn{2}{|c|}{$t$-test } \\
\hline & $\begin{array}{c}\text { Mild } \\
\text { exercise } \\
\text { (Group A) }\end{array}$ & $\begin{array}{c}\text { Moderate } \\
\text { exercise } \\
\text { (Group B) }\end{array}$ & $t$ & $\begin{array}{c}p- \\
\text { value }\end{array}$ \\
\hline \multicolumn{5}{|l|}{ Before: } \\
\hline Range & $115-240$ & $89-221$ & 0.138 & 0.891 \\
\hline Mean \pm SD & $164.950 \pm 39.364$ & $163.300 \pm 36.061$ & & \\
\hline \multicolumn{5}{|l|}{ After: } \\
\hline Range & $101-270$ & $80-210$ & 0.884 & 0.382 \\
\hline Mean \pm SD & $159.150 \pm 43.155$ & $148.100 \pm 35.575$ & & \\
\hline \multicolumn{5}{|l|}{ Paired } \\
\hline Mean \pm SD & $5.800 \pm 18.289$ & $15.200 \pm 7.046$ & & \\
\hline \multicolumn{5}{|l|}{ Paired } \\
\hline$t$ & 1.418 & 9.648 & & \\
\hline$p$-value & 0.172 & $<0.001 *$ & & \\
\hline
\end{tabular}

The mean difference value of group A is $5.800 \pm$ 18.289 while the mean difference value of group $\mathrm{B}$ is $15.200 \pm 7.046$. The rate of decrease of fasting blood glucose level of group B is greater than group A.
Table (2): Shows comparison between postprandial blood glucose level before and after exercises in both groups.

\begin{tabular}{|c|c|c|c|c|}
\hline \multirow[b]{2}{*}{ P.P } & \multicolumn{2}{|c|}{ Group } & \multicolumn{2}{|c|}{$t$-test } \\
\hline & $\begin{array}{c}\text { Mild } \\
\text { exercise } \\
\text { (Group A) }\end{array}$ & $\begin{array}{l}\text { Moderate } \\
\text { exercise } \\
\text { (Group B) }\end{array}$ & $t$ & $\begin{array}{c}p- \\
\text { value }\end{array}$ \\
\hline \multicolumn{5}{|l|}{ Before: } \\
\hline Range & $130-262$ & $110-256$ & 0.302 & 0.764 \\
\hline Mean \pm SD & $187.350 \pm 44.311$ & $183.350 \pm 39.171$ & & \\
\hline \multicolumn{5}{|l|}{ After: } \\
\hline Range & $126-275$ & $106-238$ & 0.800 & 0.429 \\
\hline Mean $\pm S D$ & $180.600 \pm 46.045$ & $169.850 \pm 38.670$ & & \\
\hline \multicolumn{5}{|l|}{ Paired } \\
\hline Mean \pm SD & $6.750 \pm 20.406$ & $13.500 \pm 6.387$ & & \\
\hline \multicolumn{5}{|l|}{ Paired samples } \\
\hline$t$ & 1.479 & 9.453 & & \\
\hline$p$-value & 0.155 & $<0.001 *$ & & \\
\hline
\end{tabular}

The mean difference values of group A is $6.750 \pm$ 20.406 while the mean difference value of group $\mathrm{B}$ is $13.500 \pm 6.387$. The rate of decrease of post prandial blood glucose level of group B is greater than group A.

Table (3): Shows comparison between male and female fasting blood glucose mean values in both groups pre and post the study.

\begin{tabular}{|c|c|c|c|c|}
\hline \multirow{2}{*}{$\begin{array}{l}\text { Fasting } \\
\text { blood } \\
\text { glucose }\end{array}$} & \multicolumn{2}{|c|}{ Sex } & \multicolumn{2}{|c|}{$t$-test } \\
\hline & $\begin{array}{c}\text { Male } \\
\text { Mean } \pm \text { SD }\end{array}$ & $\begin{array}{c}\text { Female } \\
\text { Mean } \pm \text { SD }\end{array}$ & $\mathrm{t}$ & $\begin{array}{c}p- \\
\text { value }\end{array}$ \\
\hline $\begin{array}{l}\text { - Group A } \\
\text { mild } \\
\text { exercise }\end{array}$ & & & & \\
\hline Before & $160.778 \pm 45.185$ & $168.364 \pm 35.809$ & -0.419 & 0.680 \\
\hline After & $145.000 \pm 34.172$ & $170.727 \pm 47.714$ & -1.355 & 0.192 \\
\hline $\begin{array}{l}\text { - Group B } \\
\text { moderate } \\
\text { exercise: }\end{array}$ & & & & \\
\hline Before & $192.800 \pm 16.295$ & $133.800 \pm 23.366$ & 6.550 & $<0.001 *$ \\
\hline After & $177.100 \pm 19.858$ & $119.100 \pm 20.212$ & 6.473 & $<0.001 *$ \\
\hline
\end{tabular}

Table (4): Shows comparison between male and female post prandial blood glucose mean values in both groups pre and post the study.

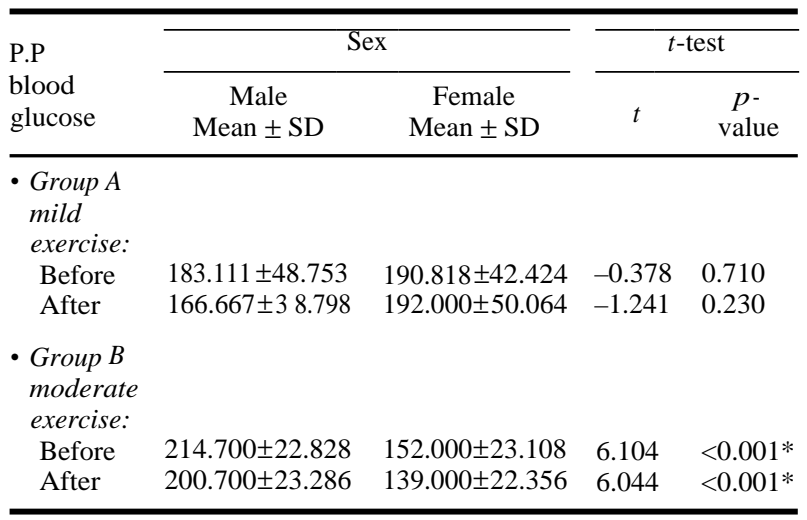




\section{Discussion}

Diabetes Mellitus (DM), commonly referred to as diabetes, is a group of metabolic diseases in which there are high blood sugar levels over a prolonged period [2]. Symptoms of high blood sugar include frequent diabetes can cause many complications [3]. Acute complications can include diabetic ketoacidosis, nonketotic hyperosmolar coma, or death [4]. Serious long-term complications include heart disease, stroke, chronic kidney failure, foot ulcers, and damage to the eyes. Diabetes also causeImmune system deficiency.

The objective was to determine the effect of mild and moderate exercise on blood glucose level (fasting and postprandial) in patients with type 2 diabetes. The objectives were accomplished through the study as there were decrease in both fasting and postprandial blood glucose level after both mild and moderate exercise particularly in group $\mathrm{b}$ who performed moderate exercise.

Maria Luiza MJ et al., [7] studied the effects of aerobic, resistance, and combined exercise on metabolic control, inflammatory markers, adipocytokines, and muscle insulin signaling in patients with type 2 diabetes. The purpose of this study was to compare the effects of 3 different modalities of exercise and he concluded that exercise training favorably affects glycemic parameters, lipid profile, blood pressure, and hs-CRP. In addition, resistance and combined training can increase IRS- 1 expression.

Sheri R. Colberg et al., [8] agreed that exercise plays a major role in the prevention and control of insulin resistance, prediabetes, GDM, type 2 diabetes, and diabetes-related health complications. Both aerobic and resistance training improve insulin action, at least acutely, and can assist with the management of BG levels, lipids, BP, CV risk, mortality, and QOL, but exercise must be undertaken regularly to have continued benefits and likely include regular training of varying types. Most persons with type 2 diabetes can perform exercise safely as long as certain precautions are taken. The inclusion of an exercise program or other means of increasing overall PA is critical for optimal health in individuals with type 2 diabetes.

Boulé NG et al., [9] stated meta-analyses on the effects of exercise estimated that for people with type 2 diabetes, both aerobic and resistance exercise improve glycemic control to an extent comparable to some oral antidiabetic drugs. Exercise should theoretically be an attractive option for people who prefer not to use drugs, or wish to obtain additional blood glucose control benefits.

Gillen JB (2012) [10] stated that a single session of continuous high-intensity exercise resulted in 60 minutes of postexercise hyperglycemia, while both a single session of High Intensity Training (HIT), and a 2-week training program have been shown to improve postprandial glucose control over a 24-hour period following exercise.

Peter OA [11] stated that a very brief High Intensity Exercise (HIE) improves Blood Glucose (BG) 1 to 3 days postexercise in both diabetics and non-diabetics. HIE is unlikely to cause hypoglycemia during and immediately after exercise. Larger and longer randomized studies are needed to determine the safety, acceptability, long-term efficacy, and optimal exercise intensity and duration.

Van Dijk JW et al., [12] a single bout of moderate-intensity exercise substantially improves glycemic control throughout the subsequent day in insulin-and non-insulin-treated type 2 diabetes patients. Of all baseline characteristics, only subjects' $\mathrm{HbA}_{1 \mathrm{c}}$ level is related to the magnitude of response to exercise. Nevertheless, the present study demonstrates that even well-controlled patients benefit considerably from the blood glucoselowering properties of daily exercise.

\section{Conclusion:}

Participating exercise decreases fasting and postprandial glucose level in patients with type 2 diabetes. Moderate exercise had a greater effect on decreasing glucose level than mild exercise.

\section{References}

1- American Diabetes Association: Standards of medical care in diabetes-2014. Diabetes Care, 37 (Suppl 1): S14S80. Doi: 10.2337/dc14-S014. Accessed January 7, 2014.

2- MICHAEL DANSINGER, M.D.: On September 03, 2014 WebMD, LLC.

3- De FERRANTI S.D., et al.: Type 1 diabetes mellitus and cardiovascular disease: A scientific statement from the American Heart Association and American Diabetes Association. Diabetes consensus recommendations for care. Diabetes Care, 31 (5): 1060-79. Also available online: http://care.diabetesjournals.org/content/31/5/ 1060. full?sid=85664cd8-932d-4050-ab55-6ecd083 ab5c8, 2014.

4- SHOBACK, edited by DAVID G. GARDNER and DOLORES: Greenspan's basic \& clinical endocrinology ( 9 th ed.). New York: McGraw-Hill medical. isbn 97800 71622431, 2011.

5- HILL J.: MayoClinic.com; Strength Training: Get Stronger, Leaner, Healthier; June 2010 
6- HASKELL W.L., LEE I.M., PATE R.R., et al.: Physical activity and public health: updated recommendation for adults from the American College of Sports Medicine and the American Heart Association. Med. Sci. Sports Exerc., 39: 1423-34, 2007.

7- MARIA LUIZA M.J., VANESSA N.O., NATHALIA M.R.A., LARA F.P., ANTONIO C., et al.: http://dx.doi.org/ 10.1016/j.metabo 1.2011.01.006.

8- SHERI R. COLBERG, RONALD J. SIGAL, BO FERNHALL, JUDITH G. REGENSTEINER, BRYAN J. BLISSMER, RICHARD R. RUBIN, LISA CHASAN-TABER, ANN L. ALBRIGHT and BARRY BRAUN: Diabetes Care. Dec., 33 (12): e147-e167/doi: 10.2337/dc10-9990, 2010.

9- BOULÉ N.G., ROBERT C., BELL G.J., et al.: Metformin and exercise in type 2 diabetes: Examining treatmentmodality interactions. Diabetes Care, 34 (7): 1469-74, [PMC free article] [PubMed], 2011.

10- GILLEN J.B., LITTLE J.P., PUNTHAKEE Z., TARNOPOLSKY M.A., RIDDELL M.C. and GIBALA M.J.: Acute high-intensity interval exercise reduces the postprandial glucose response and prevalence of hyperglycaemia in patients with type 2 diabetes. Diabetes Obes. Metab., 14 (6): 575-7, 2012.

11- PETER O.A.: Diabetes Metab. Syndr. Obes., 6: 113-22. Published online 2013 Feb. 27. doi: 10.2147/DMSO. S29222, 2013.

12- VAN DIJK J.W.1, MANDERS R.J., CANFORA E.E., MECHELEN W.V., HARTGENS F., STEHOUWER C.D. and VAN LOON L.J.: Med. Sci. Sports Exerc., Apr., 45 (4): 62835. Doi:10.1249/MSS.0b013e31827ad8b4, 2013.

13- SNOWLING N.J. and HOPKINS W.G.: Effects of Different Modes of Exercise Training on Glucose Control and Risk Factors for Complications in Type 2 Diabetic Patients A meta-analysis. Diabetes Care, 29 (11): 518-2527. http://. doi.org/10.2337/dc06-1317, 2006.

14- WILLIAM D. MCARDLE, FRANK I. KATCH and VICTOR L. KATCH: Essentials of exercise physiology. Lippincott Williams \& Wilkins. p. 204. ISBN 978-0-78174991-6. Retrieved 13 October, 2011.

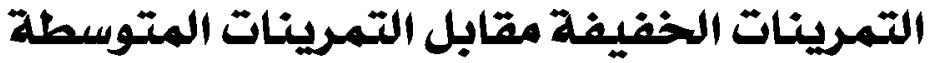

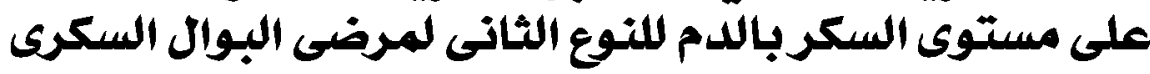

هدف الدراسة هو دراسة تآثير التمرينات الخفيفة مقابل التمرينات المتوسطة على مستوى السكربالدم اللنوع الثانى لمرضى البوال السكرى.

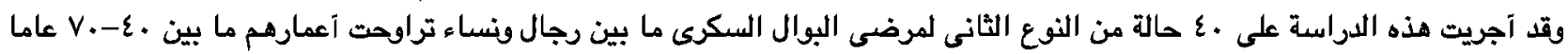

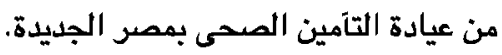

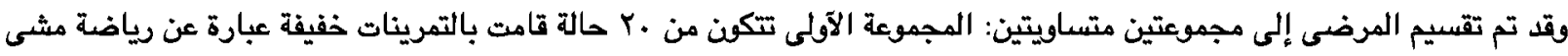

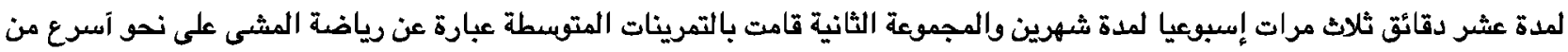

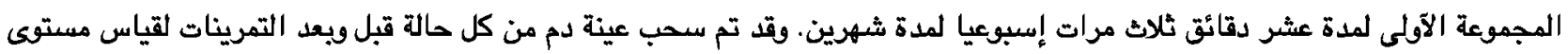

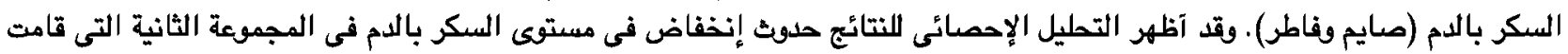
بالتمرينات المتوبسطة آكثر من المجموعة الآقلى التى قامت بالتمرينات الخفيفة. 